This is an electronic reprint of the original article. This reprint may differ from the original in pagination and typographic detail.

Author(s): Aro, Mari

Title: $\quad$ Effects of authority: Voicescapes in children's beliefs about the learning of English

Year: $\quad 2012$

Version:

Please cite the original version:

Aro, M. (2012). Effects of authority: Voicescapes in children's beliefs about the learning of English. International Journal of Applied Linguistics, 22(3), 331-346. https://doi.org/10.1111/j.1473-4192.2012.00314.x

All material supplied via JYX is protected by copyright and other intellectual property rights, and duplication or sale of all or part of any of the repository collections is not permitted, except that material may be duplicated by you for your research use or educational purposes in electronic or print form. You must obtain permission for any other use. Electronic or print copies may not be offered, whether for sale or otherwise to anyone who is not an authorised user. 
International Journal of Applied Linguistics • Vol. • • No. • • 2012

\title{
Effects of authority: voicescapes in children's beliefs about the learning of English
}

\author{
Mari Aro University of Jyväskylä, Finland
}

\begin{abstract}
This paper examines learner beliefs from a dialogical point of view. Drawing on the writings of the Bakhtin circle, it sees beliefs as shared and recycled viewpoints that are multivoiced: they echo the voices of others as well as the voice of the speaker. A longitudinal interview study was conducted among a group of young Finnish learners of English. The analysis of the data focused on the voicework present in the learners' answers: how they, on the one hand, echoed or even repeated the voices of authority, and, on the other hand, brought forward their own insights. The results indicate that the authoritative voices strongly influence how the individual viewpoints are formed and presented and may consequently also influence learner actions.
\end{abstract}

Keywords: learner beliefs, dialogism, voice, language learning

Artikkelissa tarkastellaan oppijoiden käsityksiä dialogisesta näkökulmasta. Dialogisuus perustuu ns. Bahtinin piirin kirjoituksiin, ja sen valossa käsitykset nähdään jaettuina ja kierrätettyinä näkökulmina, jotka ovat moniäänisiä: niissä kaikuvat sekä toisilta haltuunotetut äänet että puhujan oma ääni. Artikkelissa esiteltävässä pitkittäisessä haastattelututkimuksessa tarkasteltiin suomalaisten englannin oppijoiden käsityksiä. Analyysissä keskityttiin oppijoiden vastauksissa kaikuviin ääniin: sekä kaiutettaviin tai toistettaviin autoritäärisiin ääniin että oppijoiden omalla äänellään esittämiin näkemyksiin. Tulokset osoittavat, että autoritääristen äänien edustamat näkökulmat vaikuttavat vahvasti siihen, miten omat näkemykset muodostetaan ja esitetään, ja niillä saattaa näin olla vaikutusta myös oppijoiden toimintaan.

Avainsanat: käsitykset, dialogisuus, ääni, kielen oppiminen

\section{Introduction}

Research into learner beliefs began in the field of applied language studies in the early 1980s (e.g. Horwitz 1985, 1987, 1988; Wenden 1986a, 1986b, 1987; Abraham and Vann 1987; Holec 1987), sparked by an interest in how learner characteristics and contributions affected language learning. Over the past few decades, learner beliefs have mainly been looked at from two 


\section{Mari Aro}

very different perspectives. Until fairly recently, beliefs have mainly been conceptualised from a cognitive psychological viewpoint, where they are seen as characteristics of the individual, relatively stable, and something learners have "inside their head" that they can be put into words (e.g. Wenden 1986a, 1998; Horwitz 1987, 1988). When beliefs have been seen as fairly static, mental schemata possessed by the individual, they have mostly been looked at using experimental methods and quantitative measures, such as questionnaires. Radically cognitivist approaches have been justly criticised (see e.g. Sigel 1992; Barcelos 2003); however, one of the foremost alternatives in learner belief research has been to turn to exclusively socially-oriented paradigms. Learner beliefs have been seen for example, from a more discourse analytical point of view, where they are considered to be functions of social interaction, and ever-changing depending on the context of the interaction (e.g. Kalaja 1994; De Costa 2011). In the most radical approaches, what is said has been seen as exclusively socially and discursively constructed: individuals have been conceptualised as mere users of culturally and socially available resources and the focus of analysis has been on the interaction, without reference - or indeed, interest - in cognition. However, these positions have also been criticised (see e.g. Hammersley 2003, Dufva 2010). The polarised opposition between radical individualist cognitivism and radical social constructionism has resulted in a dichotomy: beliefs have for the most part been seen either as fundamentally individual, or as fundamentally social. At the same time, both extremes appear to struggle when it comes to dealing with certain central questions, such as theorising about cognising and learning.

\section{A dialogical view of learner beliefs}

This paper ${ }^{1}$ presents and adopts a dialogical view. Like certain other frameworks in the field of language studies, such as the ecological approaches (e.g. van Lier 2004), the sociocognitive approaches (e.g. Atkinson 2011), and the sociocultural approaches (e.g. Lantolf and Thorne 2006), the dialogical approach aims at transcending the dichotomy between the social and the individual. From a dialogical stance, the social and the individual are looked at as complements rather than opposites: one cannot exist without the other. A dialogical point of view on knowledge and cognition is inspired particularly by the dialogical philosophy of the so-called Bakhtin Circle (e.g. Bakhtin 1981, 1986; Voloshinov 1973), and it is also draws on various nonCartesian approaches to cognising (e.g. Järvilehto 1998; Cowley 2009). More recent contributions to the dialogical view on language studies, building on the works of the Bakhtin circle, include the works by Markova and Foppa (1990, 1991), Wertsch (1991, 1998), Rommetveit (1992), Linell (1998; 2009), Lähteenmäki (1994, 1998) and Dufva (2003, 2007, 2010); for dialogical theoretical and practical concerns specifically in foreign language learning and teaching, see Hall, Vitanova and Marchenkova (2005). 


\section{Voicescapes in children's beliefs about the learning of English -3}

Bakhtin (1984) saw his notion of dialogue not only as an act of conversation between two people, nor only as human communication using language. Dialogue, for Bakhtin, is also an overall metaphilosophical principle of interaction, governing human existence. "Life by its very nature is dialogic" (Bakhtin 1984: 293) because dialogic relationships are an almost universal phenomenon, permeating all human speech, relationships and manifestations of human life (Bakhtin 1984). Similar ideas are brought up for example, in systemic psychology (Järvilehto 1998), and ecological perspectives to learning (van Lier 2004): cognition (or rather, cognising, since it is a dynamic process, cf. Edelman 1992) is looked at in terms of an intertwined human/ environment-system, not as an activity involving two separate systems (human and environment). It is also through dialogue that humans learn and appropriate viewpoints, attitudes, memories, and other personal knowledge: through continuous interaction with the environment, both physical and social. An individual's beliefs thus have a social origin: they emerge while individuals interact with the physical world or take part in social practices, and often they emerge through the words of others (Bakhtin 1986). Beliefs are therefore rooted in social and cultural interactions - but they are not exclusively discursive or social. This is because, first, each individual has a unique life history. No two people share the exact same experiences, and therefore, the belief reservoir of each individual is unique, even if they share a culture and a social community. Second, individuals can choose to accept or not to accept the viewpoints - and their ideological contents - they come in contact with. In Bakhtin's (1981) terms, these ideological contents can be dealt with in three ways: the individual can choose to appropriate contents that he or she feels are internally persuasive and begin to use them as his or her own; ignore viewpoints he or she feels do not concern or interest him or her; or find that he or she is faced with authoritative views, words that he or she must either accept and repeat as they are, or reject them totally. Authoritative content rests on a hierarchical differentiation of power between the speakers, and, in Bakhtin's (1981: 342) words, "demands that we acknowledge it, that we make it our own; it binds us, quite independent of any power it might have to persuade us internally; we encounter it with its authority already fused in it". Authoritative content thus reflects the words of the authorities (be they moral, political or religious) which individuals must either totally affirm or totally reject. In contrast, the internally persuasive content invites and is open to contact and dialogue.

When individuals talk about their beliefs, they are typically not repeating others' words in a mechanical manner (though they can certainly choose to do so too): they are recreating and recycling the contents for their own purposes and by doing so, returning the words and their ideologies back into the social sphere. Words and ideologies thus circulate in the human/environment system, from the social realm to the individual realm, and back again. According to Voloshinov (1973), the social and the individual are in a constant, reciprocal relationship where one extends into the realm of the other, and 


\section{Mari Aro}

becomes the other. In a dialogical approach to learner beliefs, beliefs are thus not conceptualised as social or individual, but as shared; necessarily both social and individual.

As stated above, what individuals learn in interaction are not neutral words, but value-laden words containing ideological interpretations of what the world is like (Bakhtin 1981). This idea of intention and worldview embedded in words is captured in Bakhtin's concept of voice. The numerous voices an individual comes into contact with result in a knowledge reservoir that is multi-voiced, polyphonic. Certain voices are privileged (cf. Wertsch 1991), in the social community - they are more frequently repeated and more highly regarded - while others are marginalised or even silenced. This may also be evident in people's beliefs: certain beliefs may be more prevalent and therefore more readily available for verbalisation, because they circulate more frequently in the social sphere. Other beliefs may be weaker, less powerful and less readily verbalisable. The individual him/herself also privileges certain voices over others: his or her own voice, which emerges and develops through cognising activities and social practices, is constantly evolving and changing as he or she takes part in new interactions and gains new experiences (Dufva 2003). The process of development is pushed forward by dialogue with other people and the environment, and it is never complete. This process, "inner monologue" (Bakhtin 1981: 345), continues throughout the individual's lifetime.

Below, excerpts of longitudinal interview data of young learners talking about the learning of English are analysed from a dialogical viewpoint. As beliefs about language learning appear to influence the language learning process (e.g. Bandura 1986; McDonough 1995; Navarro and Thornton 2011), in-depth knowledge about beliefs not only adds to our notions of cognising, but also contributes to our comprehensive understanding of language learning. Such knowledge may also have important learning, theoretical and pedagogical implications. A dialogical reading of the data reveals whose voices are influential in the learners' beliefs: whose viewpoints are privileged and repeated, whose voices are considered authoritative, and how the various viewpoints interact. Furthermore, as the data are longitudinal, they provide the opportunity to examine the changes and variations that take place in the polyphony of the learners' beliefs over the years and thus shed light on the development of beliefs.

\section{Data and methodology}

To illustrate the concept of voice - and the role of authoritative voices in particular - in learner beliefs, interview excerpts are analysed below. The excerpts have been taken from the study reported in Aro (2009; see also Aro 2004; 2006a; 2006b). The data were collected, using semi-structured interviews, in connection with a longitudinal research project ${ }^{2}$ that followed a 


\section{Voicescapes in children's beliefs about the learning of English - 5}

group of elementary school children through school years 1-6. The study reported here looked at longitudinal interview data on how 15 Finnish L1 children - seven boys and eight girls - talked about English and learning of English as a foreign language. The children were interviewed on three occasions: in Year 1 (when they were aged 7), Year 3 (aged 9) and Year 5 (aged 11). The first year interviews were conducted by two researchers involved with the project; the third and fifth year interviews by the present author. English was introduced as a school subject in Year 3. The interviews were audiotaped and transcribed. The transcribed data were then transferred to Atlas.ti (Scientific Software Development $\mathrm{GmbH}$, Berlin) software and coded. In the analysis, the polyphony in the learners' answers was examined through several cues: the voice to be heard could be brought about by the combination of the content and formulation of what the learners said. For example, they may have used a speech genre that indexes a particular group of people or sphere of language use, reflecting the viewpoints of the same. The learners could also use the voices of others both overtly (by quoting) and more covertly (by simply mimicking, or, in Bakhtin's 1981 words, ventriloquating them). Alternatively, the learners may have clearly marked some answers as their own. The analysis of the data focused on the voicework reflected in the beliefs and its changes and variations over the years. The data analysis sought to address the following questions: what kinds of voices could be heard in the learners' beliefs, whose voices did the learners appear to consider important, and how did the various voices interact?

\section{Voicescapes of learner beliefs}

Some of the most prevalent authoritative voices in the children's beliefs were what could be called voices of society. These refer to slogans, or cultural truths, that "everyone knows" in Finland - voices and viewpoints that are frequently repeated and privileged in Finnish society. It is for example, widely accepted that "everyone" in Finland knows English. English is a compulsory subject in Finnish comprehensive schools and by far the most popular choice as the first foreign language: in 2007, approximately $90 \%$ of pupils chose it as their first foreign language (National Board of Education 2011). The 15 children participating in the study were on all three interview occasions asked why people studied English, and many children found it easy to find an answer to this question already in the first year, using oft-repeated slogans that testify to the usefulness of English skills. The following excerpt is from the third year data:

I: No minkäs takia ihmiset opiskelee englantia?

Sakari: Öö, no iskä sano ainaki et sillä pärjää joka maassa, melkeen joka maassa. 


\section{6 - Mari Aro}

I: So why do people study English?

Sakari: Er, well dad at any rate said that you can get by with it in every country, almost every country.

Sakari's answer is an obvious example of polyphony. Sakari is doing the speaking but he is openly quoting his father's words; the father's words, in turn, reflect a voice of society, a cultural truth about the role of English. The excerpt also shows how parents mediate such cultural viewpoints on to their children. The viewpoints then become recycled and reproduced in new communicative contexts by the children.

Rauli answered a similar question, also in the third year, by first trying to explain his idea of the usefulness of English in his own words:

I: No minkäs takia ihmiset sitte opiskelee englantia, mitä hyötyä siitä niille on?

Rauli: Että, kun ne menee töihin nii sitte, jos joku kysyy niiltä että, tiiätsää mitä, mitä tää tarkottaa, nii eli englantia täytyy oppia, ja sitä tarvitaan.

I: Why do people then study English, how is it useful for them?

Rauli: So that they, when they go to work so then, if someone asks them that, do you know what, what this means, so in other words English must be learnt, and it is needed.

It appears that Rauli first tried to use an example to describe how English could be used: people go to work and someone asks them something. However, after stumbling over his words slightly, he eventually resorted to using a slogan-like ending, "English must be learnt and it is needed". The end of his answer - which he presents as a summary of sorts - sounds very different from the beginning. We could say that he started answering using words that were internally persuasive, words he was familiar with, but decided in the end to appeal to a well known cultural truth: he ventriloquated the words of others. The slogan seems to indicate what in Rauli's opinion is in fact at the root of the matter: that English simply must be learnt and that this is fairly self-evident.

When the Why questions were presented in a general form ("Why is English learnt?", "Why do people study English?"), answers such as those shown in the excerpts above were a staple ever since the first year: the learners said that "English must be learnt and it is needed, one can get by using English in many countries, one needs to know English in order to be able to speak to people abroad", and so on. The learners thus appeared to feel that such ideas - all appealing to the generally accepted usefulness of English as a medium of verbal/oral communication - constituted a good answer to these questions. The basic idea behind the formulations was like a ready-made opinion, a slogan that was easily available to the learners and easy to deliver, even if they still referred to other people's words or found it difficult to explain the idea further when answering. 


\section{Voicescapes in children's beliefs about the learning of English 7}

By the fifth year the learners appeared to have appropriated the authoritative belief that "English was needed in order to be able to speak abroad". The learners could deliver it effortlessly and without an overt reference to a source, such as a parent. In the following excerpt, Aku's answer reflects the answer of the entire group of the fifth-year learners when he answers the question as he does:

I: No, minkäs takia Aku ihmiset opiskelee englantia?

Aku: Että ne osais puhua ulkomailla.

I: So why is it Aku that people study English?

Aku: So that they know how to speak abroad.

The content of Aku's answer shows, in a nutshell, how all 15 learners answered this interview question in the fifth year. All of the participants' answers contained the same authoritative idea: that English is used for talking with people, or, more specifically, talking with people abroad. The authoritative viewpoint that the learners have encountered - in talking with their parents and presumably from other people as well - is being recycled and thus further reinforced as the authoritative voice; a good reason for English studies and a good answer for questions regarding reasons for English studies.

Another type of the more authoritative voices was the voices of the school world and the classroom. Understandably, these began to emerge more in the third year data when the learners had had more experience of going to school. The voice of the school could be heard in for example, special classroom terminology that the learners began to use to describe the business of learning English. In the following excerpt, Mervi, in the fifth year, talked of the kinds of things she did in order to learn English:

I: No mitenkäs sää opiskelet englantia minkälaisia asioita sää teet koulussa ja kotona?

Mervi: No, meillä o aina kaikkia kuuntelutehtäviä ja, sit meijän pitää esittää joku, tai meillä on aina joku satu ja sit meijän pitää se ryhmän kanssa lukee ja, ja, sitte, meillä on ihan tavallisia kotitehtäviä sitte englanniks.

I: Well how do you study English what kinds of things do you do at school and at home?

Mervi: Well, we always have these listening comprehension exercises and, then we have to perform a, or we always have a fairy tale and then we have to read it with the group and, and, then, we have just ordinary homework then in English.

As Mervi's answer illustrates, the learners began to appropriate specific terms that the school environment provided them with. Their answers started to include school-specific and school-taught terms such as "homework, vocabulary lists, exams, revising, translating, listening comprehension 


\section{8 - Mari Aro}

exercises" and so on. In addition to using school-specific vocabulary, the children also began to speak "like pupils" and to voice themselves as learners in the classroom. Examples of this included references to institutional authority, so that the learners voiced themselves as obedient pupils. As an example, Mervi, in the excerpt above, says that the learners have to read and have to perform, and in saying so she thus indicates that the learners are under the power of the authority of the teacher and the school system. Similar ideas were recycled by many other learners too. A further illustration of the authority of the school institution is shown in the next excerpt, also from the fifth year data, where Matti talks about the differences of learning maths and learning English:

I: No onks englannin opiskelu sun mielestä erilaista ku vaikka matikan opiskelu?

Matti: No on se nii, jotenki erilaista ku, joutuu s- vaikka sanomaan toisille (ja), matikassa saa ite päättää mikä, mikä on vastaus. Englannissa pitää olla kaikki niinku oikee, niinku matikassaki.

I: So do you think studying English is different from say studying maths?

Matti: Well yes it is, somehow different coz, you have to s- for example say to others (and), in maths you get to decide by yourself what the answer is. In English everything has to be like correct, like in maths too.

Matti states that one has to do various things as a pupil, and also that these things have to be correct. Not only is the school authority telling learners what to do, Mattis' answer also indicates that at school there is the one correct, predefined answer that a learner can manage to land on: from the learners' point of view, it appears that the school tells them what to do and then assesses if it was done in the correct manner. In many ways, the school thus has a very authoritative voice that the learners react to: both by appropriating its words and by responding to its demands. Karasavvidis, Pieters and Plomp (2000) point out that one of the demands of the school is precisely to "appropriate its words", to learn the subject-specific vocabulary; when the student has appropriated the right words and concepts, it is considered that he or she has in essence learnt the task. The view of Karasavvidis et al. (2000) is supported by the observation that teachers often explicitly forbid the students to explain things in their own words and emphasise that the point of the task is to acquire the appropriate way of speaking (Karasavvidis et al. 2000). It is thus no wonder that the learners echo the voice of the school world in their interview answers, too.

The discourses and practices of the school also influenced how the learners said English should be learnt. Some of the learners said that in order to learn English one should go to school or attend a course - it was, after all, what they themselves were doing. However, the learners also appeared convinced that one learnt English through written language, most importantly by reading books, as shown in the excerpts below: 


\section{Voicescapes in children's beliefs about the learning of English - 9}

I: No, mitenkäs englantia opiskellaan jos joku haluaa oikei hyvin oppia englantia nii mitä sen kannattaa tehdä?

Emma: Lukee niitä sanoja ja harjotella kirjottamaan niitä.

I: Well, how does one study English if one wants to learn English really well what should they do?

Emma: Read the words and practice how to write them.

I: Miten englantia vois oppia ilman opettajaa?

Aku: Ostaa enkun kirjan.

I: How could one learn English without a teacher?

Aku: Buy an English textbook.

According to Emma, one ought to read words and practice writing them in order to learn English. Aku talked about what happens if the language teacher is taken out the equation: in order to learn English without a teacher, one ought to get an English textbook. It may be that, in this case, the appropriated belief was conveyed through classroom practices - also a dialogical enterprise - rather than the words of others: it was acted out rather than spoken. Language lessons at schools have been found to be fairly book-centric: the teachers tend to refer to the textbooks a great deal and most of the activity in the classroom is focused on them (see e.g. Pitkänen-Huhta 2003). It therefore seems likely that the answers cited above echo the learners' own experiences of learning English and thereby provide them with an idea of how others could learn, too. Whatever the case, the majority of the learners stated that what was to be learnt was to be found in a book, and one could learn it there by reading: their descriptions of learning activities were very focused on written language.

Over time and as their experiences accumulated, the learners began to rely less and less on repeating the words of others. Instead, they began to bring forth their own, personal experiences of learning and using English when answering the interview questions. By the fifth year, they started, for example, to use their own experiences as grounds for their answers: they said that they held a particular view about learning English because of their own learning experiences. In the following excerpt, fifth-year learner Jari was asked about the usefulness of watching English-language television programmes in learning English:

I: Luuleksää että, kun kattelee semmosia englanninkielisiä ohjelmia sitte nii luuleksää et siitä vois olla hyötyä enkun opinnoissa?

Jari: Mmh. Emmää kyllä usko.

I: Joo.

Jari: Emmää ainakaa opi kyllä siitä paljoo.

I: Do you think that, when one then watches English-language programmes do you think they might be useful for one's English studies?

Jari: Mmh. I don't think so really.

I: Yeah.

Jari: I for one don't learn much from it. 


\section{0 - Mari Aro}

In his answer Jari first said that he did not think watching English-language programmes on the television would be useful in helping one learn English, and then added that he, for one, did not feel as if he learnt much from it. He thus indicated that the reason that he said that he did not find Englishlanguage programmes useful in general was because he himself did not find them useful. Phrases such as those used by Jani were frequent in the fifth year data: when the learners talked about things they did not find useful for the learning of English (be it watching television or listening to Englishlanguage music), they usually stated it was because it was not useful for me, anyway. Such comments underscored that the answers were based on the learner's own experiences, but they may also have served as hedging comments: while the learner himself or herself did not find a particular activity helpful, they did not wish to suggest that this would be categorically true for all learners.

Not only did the learners' own experiences function as a reason for answering a question in a particular way, the experiences sometimes also provided the content of the answer. Sometimes the learners appeared to use their own life events or encounters with English as examples or illustrations, as the excerpt below illustrates:

I: Miten siit on hyötyä että osaa englantia?

Matti: No osaa vaikka tilata jotai ruokaa tai sitte, sitte jos ostaa jotai ni, osaa, pyy- kysyä paljonko se maksaa. (. . . )

I: Minkäslaisissa paikoissa sää muistat et sä oot törmänny englantiin nyt vaikka viimesen viikon aikana?

Matti: Emmää viimesen viiko aikana mutta, en muista kuinka kauan siitä on mutta Curaçaolla törmäsin englantiin.... lentokoneessa tilasin ite ruokia ja.

I: How is it useful for one to know English?

Matti: Well one can for example order some food or then, then if one buys something so, then one can, ask how much it costs. (...)

I: In what kinds of places have you come across the English language, say, during the past week?

Matti: Not during the past week but, I can't remember how long ago it was but in Curaçao I came across English... I ordered some food on the airplane and.

Early on in the interview, Matti listed examples of things one could do if one knew English: order some food, ask how much it costs. Later, he talked about the holiday he had had in Curaçao, and mentioned that he had ordered food on the airplane in English. The activities he had earlier used as examples of using English were probably also the kinds of things he had done or seen others do during his holiday: ordering food and asking how much things cost are typical tourist interactions. Like many other learners in the fifth grade, Matti thus appeared to feel confident citing his own experiences of how English could be used as a general answer to a general question. 
Voicescapes in children's beliefs about the learning of English 11

\section{Effects of authority}

In light of the interview data, it seemed that as soon as the learners had some personal experience of something connected to learning and using the English language, such experience immediately found its way to their interview answers. The learners, in fact, seemed to look for ways to make their own increasing expertise known, adding "side notes" to their answers and referring to their own encounters even when they were not, strictly speaking, relevant to the question they were answering. However, it seemed that these voices of personal experience were in fact conditioned by the authoritative voices (Bakhtin 1981) of society and school: that the authoritative voices got to define how the learners' own experiences were interpreted; that the learners' own voices were spoken through the authoritative voice.

As mentioned earlier, one of the authoritative "cultural truths" was that English is needed for speaking to foreigners abroad. If it is considered that using English means speaking it in a foreign country, then, consequently, not going abroad to talk to people means that one is not using English. In the above excerpt, Matti was in fact asked if he had come across the English language over the past week, when he had been in his home town, attending school and living his regular everyday life. The English language is omnipresent in Finland: foreign language television programmes and movies are not dubbed; there are plenty of English-language advertisements and commercials that are brought to Finland as-is; there is the Internet along with computer games and console games, all with English content; the children attend English classes at school, and so on. Despite all of the English language surrounding the children in their everyday lives, none of these examples made it into Matti's answer. Instead, he referred to something that had happened months earlier but that was compatible with the authoritative belief and its basic notion of speaking to foreigners abroad: when I was in Curacao I came across English. In the same way, if the belief is that using English means speaking it, it was understandably difficult for the learners to think how the ability to read English could be useful. When asked how being able to read English could be useful, Jari - who appeared to be quite baffled by the question - simply said that it, too, is a skill (see Table 1). Like most of the young learners who were interviewed in the study, he found the questions regarding the usefulness of written forms of English difficult, and could not come up with a scenario where being able to read English could be useful. It appeared that, as, for the children, using English meant speaking it, being able to specifically speak English was also the reason for learning it. Consequently, the uses for writing and reading skills of English appeared to be somewhat of a mystery for these young learners.

In the third example in Table 1, Maija answered the question "Do you need English, do you use it anywhere?" The girl, in fact, had a very valid way of using English. A need she had was met by speaking in English: when she wanted to communicate something to her mother, but wanted to make sure 
JOBNAME: No Job Name PAGE: 12 SESS: 16 OUTPUT: Mon Apr 23 16:52:19 2012

/v2451/blackwell/journals/ijal_v0_i0/ijal_314

\section{2 - Mari Aro}

Table 1. The effects of the authoritative belief about why English is studied

\begin{tabular}{|c|c|}
\hline Authoritative belief & Learner beliefs \\
\hline $\begin{array}{l}\text { English is needed } \\
\text { for speaking to } \\
\text { foreigners abroad }\end{array}$ & $\begin{array}{l}\text { Not during the past week but, I can't remember how long ago } \\
\text { it was but when I was in Curaçao I came across English. } \\
\text { Well, I suppose [being able to read English] too is a skill. } \\
\text { Well, I don't really, need it as such but sometimes if there's } \\
\text { something with the little sister, so that one wants to go } \\
\text { somewhere and the little sister cannot come along so one } \\
\text { says it to mom in English, then the sister won't } \\
\text { understand. }\end{array}$ \\
\hline
\end{tabular}

Table 2. The effects of the authoritative belief about how English is studied

\begin{tabular}{ll}
\hline Authoritative belief & Learner beliefs \\
\hline $\begin{array}{l}\text { English is learnt } \\
\text { through books, } \\
\text { primarily at school }\end{array}$ & $\begin{array}{l}\text { Well one should go study it at school } \\
\text { Read the words and practice how to write them. } \\
\text { or a comic] there was a vocabulary list where one could } \\
\text { look them up, the words then one could learn the words at } \\
\text { the same time too. }\end{array}$
\end{tabular}

her little sister could not understand what she was saying, she spoke to her mother in English. Yet, in her opinion, using English at home to communicate did not constitute really needing English as such.

The world of school also appeared to supply the learners with an authoritative belief. Its effect, however, did not seem to be quite as powerful as that of the cultural truth regarding why English is learnt. The voice of the school attended to the question of how English is learnt, and stated that English is learnt through books, primarily at school. The learners appeared to view learning through this authoritative filter: in their answers, learning took place mostly at school or on a language course, and always by reading books. In the first excerpt of Table 2, Sakari - then a fifth year pupil - was asked how English is learnt: what should one do in order to learn English? Well one should go study it at school was his answer. Emma, also in the fifth year, was asked: how does one learn English? She answered by saying read the words and practice how to write them - both written activities. The idea that English is learnt from books also affected how the children viewed learning opportunities outside of the classroom. Written language material was considered useful: the learners said that reading English novels or comics would be useful for one's English studies, as would computer or console 
Voicescapes in children's beliefs about the learning of English 13

games, insofar as the speech of the game characters was also written on the screen. English-language television programmes or English-language pop and rock music were not considered helpful in learning English, because they featured spoken or sung language, which the learners found difficult to follow and understand. Even with written material encountered outside of the classroom, the model that the school gave of learning activities ruled supreme, as illustrated by the third excerpt in Table 2. One of the learners stated, in a fifth year interview, that reading novels and comics in English would be useful for the learning of English, especially if the publications came with a vocabulary list - a list of English words and their Finnish equivalents, like the ones they had in their English textbooks at school.

The learners' views of how to learn and use English thus appeared to be influenced by authoritative voices circulating frequently in the social sphere and reinforced by practices of the school. An interesting observation on the two authoritative viewpoints is also how they seem to contradict each other in the learners' interview answers: one learns English in order to be able to speak it, yet it is learnt almost exclusively through written language. The authoritative voice of society, attending to the why questions, privileged oral forms of language, while the authoritative voice of the school, evident in the how questions, privileged written language. When these two views are put together, it seems that one learns to speak English by reading it.

\section{Concluding remarks}

The analysis of the interview data in this paper provided insight into the voicescapes of learners' beliefs. It appears that there are certain fairly powerful and authoritative viewpoints in learner beliefs that have been appropriated early on, and that may consequently strongly influence what the children perceive and consider important in learning and using English. These are not only authoritative voices in the sense that one needs to repeat the words as they are (cf. Bakhtin 1981); they also appear to be authoritative viewpoints the validity of which one needs to accept. Consequently, they appear to affect how learners see and value various things connected to the English language. Such beliefs may thus influence how the children voice themselves as learners and users of English - and whether they, in fact, see themselves as learners and users of English at all - what kinds of things learners deem important and worthwhile when learning and using the language, and how learners view learning opportunities both in and outside of the classroom. A learner may consequently feel that he or she is learning only when he or she is studying with a text book, or feel that his or her everyday uses of English are not important or relevant. While the study reported here was conducted in a Finnish context with young learners of English, a dialogical reading of learner beliefs using Bakhtin's concepts, such as polyphony and authority, will certainly prove useful in various other 


\section{4 - Mari Aro}

contexts as well. An analysis of the polyphony of learner beliefs may well provide us with new perspectives on which beliefs are privileged and are therefore likely to have an actual impact on how learners go about learning a language, and consequently, what kinds of learner beliefs both teachers and learners themselves might need to be aware of. Such knowledge may also lead to a need to re-evaluate current pedagogical practices.

\section{Notes}

1. This paper is produced in the context of research project 'Dialogues of Appropriation', directed by Hannele Dufva and funded by the Academy of Finland, and science workshop 'Agency and Languaging', directed by Hannele Dufva and funded by the Finnish Cultural Foundation.

2. 'Situated metalinguistic awareness and foreign language learning', directed by Riikka Alanen and funded by the Academy of Finland.

\section{References}

Abraham, R. G., and R. J. Vann (1987) Strategies of two language learners: a case study. In A. Wenden and J. Rubin (eds.), Learner strategies in language learning. London: Prentice-Hall International. 85-102.

Aro, M. (2004) Voice and agency in children's beliefs about the English language and language learning. In M. Nenonen (ed.), Papers from the 30th Finnish Conference of Linguistics, Joensuu, 15-16 May 2003. University of Joensuu. 8-14.

- (2006a) Anteeksi, kuka puhuu? Lasten kielikäsitysten moniäänisyydestä. In R. Alanen, H. Dufva and K. Mäntylä (eds.), Kielen päällä. Näkökulmia kieleen ja kielenkäyttöön. Jyväskylä: Centre for Applied Language Studies. 53-76.

- (2006b) Kannattaa lukea paljon, että oppii puhumaan: viidesluokkalaisten käsityksiä englannin kielen osaamisesta ja opettamisesta. In P. Pietilä, P. Lintunen and H.-M. Järvinen (eds.), Kielenoppija tänään - language learners of today. AFinLA Yearbook 64. Jyväskylä: The Finnish Association of Applied Linguistics, 87-103.

- (2009) Speakers and doers. Polyphony and agency in children's beliefs about language learning. Jyväskylä Studies in Humanities 116. University of Jyväskylä.

Atkinson, D. (2011) A sociocognitive approach to second language acquisition: how mind, body, and world work together in learning additional languages. In D. Atkinson (ed.), Alternative approaches to second language acquisition. London: Routledge. 143-66.

Bakhtin, M. (1981) The dialogic imagination. Four essays by M. M. Bakhtin. Austin, TX: University of Texas.

- (1984) Problems of Dostoevsky's poetics. Minneapolis, MN: University of Minnesota.

- (1986) Speech genres and other late essays. Austin, TX: University of Texas.

Bandura, A. (1986) Social foundations of thought and action: a social cognitive theory. Englewood Cliffs, NJ: Prentice-Hall.

Barcelos, A. M. F. (2003) Researching beliefs about SLA: a critical review. In P. Kalaja and A. M. F. Barcelos (eds.) Beliefs about SLA: new research approaches. Dordrecht: Kluwer Academic Publishers. 7-33. 
JOBNAME: No Job Name PAGE: 15 SESS: 16 OUTPUT: Mon Apr 23 16:52:19 2012

/v2451/blackwell/journals/ijal_v0_i0/ijal_314

\section{Voicescapes in children's beliefs about the learning of English 15}

Cowley, S. (2009) Distributed language and dynamics, Pragmatics and cognition 17.3: 495-507.

De Costa, P.I. (2011) Using language ideology and positioning to broaden the SLA learner beliefs landscape: the case of an ESL learner from China. System 39.3: $347-58$.

Dufva, H. (2003) Beliefs in dialogue: a Bakhtinian view. In P. Kalaja and A. M. F. Barcelos (eds.) Beliefs about SLA: new research approaches. Dordrecht: Kluwer. 131-151.

- (2007) Embodied languaging in a social world. Paper presented at the Social and Cognitive Aspects of Second Language Learning and Teaching Conference 2007. 12 April, Auckland, New Zealand

- (2010) Reclaiming the mind: dialogism, language learning and the importance of considering cognition. In K. Junefelf and P. Nordin (eds.) Proceedings of the Second International Interdisciplinary Conference on Perspectives and Limits of Dialogism in Mikhail Bakhtin. 3-5, June 2009. Stockholm: University of Stockholm. 41-48.

Edelman, G. M. (1992) Bright air, brilliant fire. Harmondsworth: Penguin.

Hall, J. K., G. Vitanova, and L. Marchenkova (eds.) (2005) Dialogue with Bakhtin on second and foreign language learning: new perspectives. Mahwah, NJ: Lawrence Erlbaum.

Hammersley. M. (2003) Conversation analysis and discourse analysis: methods or paradigms? Discourse and Society 4.6: 751-81.

Holec, H. (1987) The learner as manager: managing learning or managing to learn? In A. Wenden and J. Rubin (eds.), Learner strategies in language learning. London: Prentice-Hall, 145-57.

Holquist, M., and C. Emerson (1981) Glossary. In M. Holquist (ed.), The dialogic imagination. Four essays by M. M. Bakhtin. Austin, TX: University of Texas. 423-34.

Horwitz, E. K. (1985) Using student beliefs about language learning and teaching in the foreign language methods course. Foreign Language Annals 18.4: 333-40.

- (1987) Surveying student beliefs about language learning. In A. Wenden and J. Rubin (eds.) Learner strategies in language learning. London: Prentice-Hall. 119-29.

- (1988) The beliefs about language learning of beginning university foreign language students. The Modern Language Journal 72.3: 283-94.

Järvilehto, T. (1998) The theory of the organism-environment system: I. Description of the theory. Integrative Physiological and Behavioural Science 33.4: 321-34.

Kalaja, P. (1994) Vieraiden kielten oppijoiden käsitykset kielenoppimisesta: vaihtoehtoista määrittelyä ja tutkimusta [Foreign language learners' perceptions of language learning: an alternative definition of research]. FINLANCE. A Finnish Journal of Applied Linguistics 14.1: 50-66.

Karasavvidis, I., J. M. Pieters, and T. Plomp (2000) Investigating how secondary school students learn to solve correlational problems: quantitative and qualitative discourse approaches to the development of self-regulation. Learning and Instruction 10.3: 267-92.

Lantolf, J., and S. L. Thorne (2006) Sociocultural theory and the genesis of second language development. Oxford: Oxford University Press.

Linell, P. (1998) Approaching dialogue. Talk, interaction and contexts in dialogical perspectives. Amsterdam: John Benjamins.

- (2009) Rethinking language, mind and world dialogically: interactional and contextual theories of human sense-making. Charlotte, NC: Information Age Publishing. 
JOBNAME: No Job Name PAGE: 16 SESS: 16 OUTPUT: Mon Apr 23 16:52:19 2012

/v2451/blackwell/journals/ijal_v0_i0/ijal_314

\section{6 - Mari Aro}

Lähteenmäki, M. (1994) Consciousness as a social and dialogical phenomenon. FINLANCE. A Finnish Journal of Applied Linguistics 14.1: 1-21.

- (1998) On dynamics and stability: Saussure, Voloshinov, and Bakhtin. In M. Lähteenmäki and H. Dufva (eds.) Dialogues on Bakhtin: interdisciplinary readings. Jyväskylä: Centre for Applied Language Studies. 51-69.

Markova, I., and K., Foppa (eds.) (1990) Dynamics of dialogue. New York: Prentice-Hall. - (1991) Asymmetries in dialogue. New York: Prentice-Hall.

McDonough, S. H. (1995) Strategy and skill in learning a foreign language. London: Edward Arnold.

National Board of Education [Opetushallitus]. http://www.oph.fi (accessed 3 January 2011).

Navarro, D., and K. Thornton (2011) Investigating the relationship between belief and action in self-directed language learning. System 39.3: 290-301.

Pitkänen-Huhta, A. (2003) Texts and interaction. Literacy practices in the EFL classroom. Jyväskylä Studies in Languages 55. Jyväskylä: University of Jyväskylä.

Rommetveit, R. (1992) Outlines of a dialogically based social-cognitive approach to human cognition and communication. In A. H. Wold (ed.) The dialogical alternative. Towards a theory of language and mind. Oslo: Scandinavian University Press. 19-44.

Sigel, I. E. (1992) The belief-behavior connection: a resolvable dilemma? In I. E. Sigel, A.V. McGillicuddy-DeLisi and J. J. Goodnow (eds) Parental belief systems: the psychological consequences for children. Hillsdale, NJ: Lawrence Erlbaum. 433-56.

Voloshinov, V. N. (1973) Marxism and the philosophy of language. London: Seminar Press. van Lier, L. (2004) The ecology and semiotics of language learning. A sociocultural perspective. Boston, MA: Kluwer Academic Publishers.

Wenden, A. L. (1986a) What do second-language learners know about their language learning? A second look at retrospective accounts. Applied Linguistics 7.2: 186-205.

- (1986b) Helping language learners think about learning. ELT Journal 40.1: 3-12.

- (1987) Metacognition: an expanded view of the cognitive abilities of L2 learners. Language Learning 37.4: 573-97.

Wertsch, J. V. (1991) Voices of the mind. A sociocultural approach to mediated action. Cambridge, MA: Harvard University Press.

- (1998) Mind as action. New York: Oxford University Press. 
JOBNAME: No Job Name PAGE: 17 SESS: 16 OUTPUT: Mon Apr 23 16:52:19 2012 /v2451/blackwell/journals/ijal_v0_i0/ijal_314

\begin{tabular}{|l|l|}
\hline \multicolumn{2}{|c|}{ Toppan Best-set Premedia Limited } \\
\hline Journal Code: IJAL & Proofreader: Elsie \\
\hline Article No: 314 & Delivery date: 25 April 2012 \\
\hline Page Extent: 16 & \\
\hline
\end{tabular}

\section{AUTHOR QUERY FORM}

Dear Author,

During the preparation of your manuscript for publication, the questions listed below have arisen. Please attend to these matters and return this form with your proof.

Many thanks for your assistance.

\begin{tabular}{|l|l|l|}
\hline $\begin{array}{c}\text { Query } \\
\text { References }\end{array}$ & \multicolumn{1}{|c|}{ Query } & Remark \\
\hline $\mathrm{q} 1$ & $\begin{array}{l}\text { AUTHOR: Wenden, 1998 has not been } \\
\text { included in the Reference List, please } \\
\text { supply full publication details. }\end{array}$ & \\
\hline
\end{tabular}




\section{Please correct and return this set}

Please use the proof correction marks shown below for all alterations and corrections. If you wish to return your proof by fax you should ensure that all amendments are written clearly in dark ink and are made well within the page margins.

\begin{tabular}{|c|c|c|}
\hline Instruction to printer & Textual mark & Marginal mark \\
\hline Leave unchanged & ... under matter to remain & ( ) \\
\hline $\begin{array}{l}\text { Insert in text the matter } \\
\text { indicated in the margin }\end{array}$ & $h$ & $\begin{array}{l}\text { New matter followed by } \\
h \text { or } h \otimes\end{array}$ \\
\hline Delete & $\begin{array}{l}\text { I through single character, rule or underline } \\
\text { or }\end{array}$ & $\sigma$ or $\sigma(x)$ \\
\hline $\begin{array}{l}\text { Substitute character or } \\
\text { substitute part of one or } \\
\text { more word(s) }\end{array}$ & I through letter or & $\begin{array}{l}\text { new character / or } \\
\text { new characters / }\end{array}$ \\
\hline Change to italics & — under matter to be changed & $\leftarrow$ \\
\hline Change to capitals & $\equiv$ under matter to be changed & $\equiv$ \\
\hline Change to small capitals & $=$ under matter to be changed & $=$ \\
\hline Change to bold type & $\sim$ under matter to be changed & $\sim$ \\
\hline Change to bold italic & $\bar{\sim}$ under matter to be changed & $\tilde{\omega}$ \\
\hline Change to lower case & Encircle matter to be changed & $\Rightarrow$ \\
\hline Change italic to upright type & (As above) & \\
\hline Change bold to non-bold type & (As above) & \\
\hline Insert 'superior' character & $\begin{array}{l}/ \text { through character or } \\
K \text { where required }\end{array}$ & $\begin{array}{l}y^{\prime} \text { or } y \\
\text { under character } \\
\text { e.g. } y^{2} \text { or } y^{2}\end{array}$ \\
\hline Insert 'inferior' character & (As above) & $\begin{array}{l}\lambda \\
\text { over character } \\
\text { e.g. } \hat{\Sigma}\end{array}$ \\
\hline Insert full stop & (As above) & $\odot$ \\
\hline Insert comma & (As above) & , \\
\hline Insert single quotation marks & (As above) & $\begin{array}{l}\dot{y} \text { or } \dot{x} \text { and/or } \\
\dot{y} \text { or } \dot{y}\end{array}$ \\
\hline Insert double quotation marks & (As above) & $\begin{array}{l}\ddot{y} \text { or } \ddot{x} \text { and/or } \\
\ddot{y} \text { or } \ddot{x}\end{array}$ \\
\hline Insert hyphen & (As above) & 1 \\
\hline Start new paragraph & 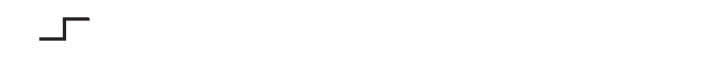 & 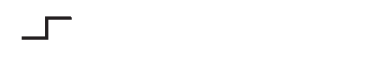 \\
\hline No new paragraph & $\infty$ & $\omega$ \\
\hline Transpose & $\sqcup$ & $\sqcup$ \\
\hline Close up & linking $\bigcirc$ characters & \\
\hline $\begin{array}{l}\text { Insert or substitute space } \\
\text { between characters or words }\end{array}$ & $\begin{array}{l}\text { I through character or } \\
K \text { where required }\end{array}$ & \\
\hline $\begin{array}{l}\text { Reduce space between } \\
\text { characters or words }\end{array}$ & $\begin{array}{l}\text { between characters or } \\
\text { words affected }\end{array}$ & $\uparrow$ \\
\hline
\end{tabular}

